\title{
Effective entrepreneurial narrative design in reward crowdfunding campaigns for social ventures
}

\author{
Veronica De Crescenzo ${ }^{1}$ (1) - Angelo Bonfanti ${ }^{1}$ (i) Paola Castellani ${ }^{1}$ (I) \\ Alfonso Vargas-Sánchez ${ }^{2}$ (I)
}

Accepted: 4 August 2021 / Published online: 14 January 2022

(c) The Author(s), under exclusive licence to Springer Science+Business Media, LLC, part of Springer Nature 2021

\begin{abstract}
One of the most important challenges for social venture entrepreneurs is acquiring resources. Reward crowdfunding is considered a suitable tool for meeting the financing needs of social ventures, whose backers are particularly interested in firm ideas and core values rather than in collaterals or business plans. A strategic factor that is able to influence the outcome of crowdfunding campaigns is the entrepreneurial narrative. Very few scholars have examined the key factors that support a crowdfunding campaign, particularly those on reward-based crowdfunding platforms, and the effects of entrepreneurial narratives on investors' decisions. Aiming to fill this research gap, this paper investigates how entrepreneurs in the technology industry describe their social ventures and projects on Eppela, an Italian reward-based crowdfunding platform. Thematic analysis was applied to detect the five following key factors of effective entrepreneurial narratives in reward-based crowdfunding campaigns for social ventures: 1) problem/need; 2) project; 3) product; 4) team; and 5) venture. Each key factor includes specific subfactors. Lexical data analysis was then performed to identify the following expected effects of the examined entrepreneurial narratives on potential investors, leading these investors to understand, trust, and approve the project proposal, and thus, finance the social venture's project: 1) reassurance, 2) reliability, and 3) credibility. Based on these results, this study proposes an explanatory model about how to design effective entrepreneurial narratives to be presented to contribute as much as possible to the success of projects in crowdfunding platforms.
\end{abstract}

Keywords Narrative text $\cdot$ Social crowdfunding campaigns $\cdot$ Reward-based crowdfunding platforms $\cdot$ Social venture $\cdot$ Project design

Veronica De Crescenzo

veronica.decrescenzo@univr.it

Extended author information available on the last page of the article 


\section{Introduction}

Unlike charities and nonprofit organizations, social ventures "create and sell products or services that improve the quality of life of low-income or disadvantaged people, while earning revenues for the business to support and grow their businesses" (Etchart \& Comolli, 2013: 1). Therefore, social ventures focus on the partial use of market-based approaches to address wider social issues and access sustainable commercial revenue sources (Kerlin, 2010; Lehhner \& Nicholls, 2014). Social ventures are distinct for their ability to stimulate the economy and have a positive impact on social issues that the public and private sectors are unable to tackle. That is, social ventures aim to meet unmet social needs by creating both social and economic value, rather than by simply focusing on returning a profit to stakeholders (Acs et al., 2013; Nicholls, 2008). Thus, social ventures operate by supplying goods and services in accordance with an entrepreneurial model and using innovation to provide solutions to social problems (e.g., Austin et al., 2006; Bonfanti et al., 2016; Choi \& Majumdar, 2014; Mair \& Martí, 2006). Social ventures are a relevant phenomenon in relation to services delivered and workers employed (European Commission, 2020) and they play a strategic role in the Italian economy. In the Italian context, social ventures tend to be more widespread in the North of Italy and in the social and healthcare sector (Carini \& Lori, 2020). It has been estimated that in 2015, the production value of Italian social ventures amounted to approximately $€ 50$ billion, which represents $3 \%$ of Italian gross domestic profit (Chiaf, 2020); however, because of the Covid19 pandemic, in 2020, $73 \%$ of Italy's social ventures were forced to reduce their activities (Isnet, 2020).

One of the most important challenges for social venture entrepreneurs is acquiring resources. Conventional and consolidated sources of finance seem inappropriate for sustaining the growth of social ventures because of the differences between this type of venture and traditional for-profit ventures (Fedele \& Miniaci, 2010; Ridley-Duff, 2008). To overcome this problem, crowdfunding was born as a new source of finance that enables entrepreneurs to exhibit their idea or project on a digital platform (Belleflamme et al., 2014; Kraus et al., 2016). More precisely, crowdfunding, which is often referred to as a "reward-based model", is considered a useful tool for meeting the financing needs of social ventures given that their backers are most interested in the ideas and core values of the firm than in collaterals or business plans (Lehner, 2013; Lehhner \& Nicholls, 2014).

The relevance of the crowdfunding market is growing in the European context. The number of reward-based crowdfunding platforms and crowdfunding projects, as well as the total amount raised by crowdfunding, have increased significantly in recent years. In Europe, excluding the United Kingdom market, the reward-based crowdfunding volume grew from US\$83.8 million to US\$175.4 million between 2013 and 2018 (Cambridge Centre for Alternative Finance, 2020: 78). In Italy, reward-based crowdfunding still accounts for a larger share of the market than does equity-based crowdfunding because of the regulatory framework that has influenced the growth of the latter (Cambridge Centre for Alternative Finance, 2019). 
The literature identifies one of the factors influencing reward crowdfunding campaigns as project presentation (e.g., Madrazo-Lemarroy et al., 2019; Mollick, 2014). When aiming to empower crowdfunding campaign communication, social venture entrepreneurs must provide a clear and interesting crowdfunding proposal to be published on the platform webpage (e.g., Boeuf et al., 2014; Gafni et al., 2019) in such a way that potential backers can understand and evaluate the characteristics of each venture and project (Colombo et al., 2015). That is, entrepreneurs must narrate the company's project, business, and story (Guo et al., 2019; Miglietta et al., 2015) to establish legitimacy and acquire capital (Martens et al., 2007). Thus, in a venture's relationship with potential backers, appropriate project presentation is a critical element of any crowdfunding proposal. Previous studies have analyzed reward-based crowdfunding campaigns through focusing on different successful strategic factors such as the project's nature (e.g., Mollick, 2014); scope (e.g., Mollick, 2014; Robertson \& Wooster, 2015); duration (e.g., Chan \& Parhankangas, 2017; Colombo et al., 2015; Cordova et al., 2015); and communication tools (e.g., Belleflamme et al., 2014; Colombo et al., 2015; Kraus et al., 2016).

Other studies have examined how entrepreneurs present their ideas or projects via text, videos, pictures, blogs, and other online elements (e.g., Kaminski \& Hopp, 2020; Kraus et al., 2016; Mollick, 2014; Petitjean, 2018; Zheng et al., 2014) in a way that contributes to descriptions that can deliver an emotional or rational appeal (Baber, 2020). Research on the role of media content in the crowdfunding phenomenon is extremely important because it will "give rise to a series of guidelines that can help entrepreneurs maximise their chances of success" (McKenny et al., 2017: 297). However, to the best of our knowledge, little attention has been paid to how social ventures can effectively empower their crowdfunding campaigns in textual content terms.

This paper aims to fill this research gap by investigating how social ventures are designing the presentation of their projects on crowdfunding platforms effectively. Precisely, the purpose of this research is twofold. First, this study detects key factors (and subfactors) of effective entrepreneurial narrative design in reward crowdfunding campaigns for social ventures. Second, the study identifies the expected effects that these entrepreneurial narratives should have on potential investors in a way that leads them to understand, give trust, and approve the project proposal, and therefore, finance the social venture's project. Based on the results of these analyses, the study proposes an explanatory model to demonstrate how to design effective entrepreneurial narratives that can provide maximum contribution to the success of projects in crowdfunding platforms.

The study employs a qualitative research method by both performing thematic analysis of crowdfunding projects to detect key factors and subfactors of entrepreneurial narratives, and employs lexical analysis to identify the expected effects of these entrepreneurial narratives. Eppela was selected as the case study because it is one of the more active and longest running reward-based crowdfunding platforms in Italy, with a success rate of $65 \%$, corresponding to more than 6,000 projects financed at the end of 2020 (https://www.eppela.com/it/support). For this study, only technological social ventures searching for funds and being successfully funded from 2017 until the end of June 2021 were investigated because these ventures represent a more 
suitable sample of projects than those of social ventures operating in other sectors found in Eppela.

This study contributes to improving knowledge on social ventures in the crowdfunding campaign context in several ways. From a theoretical perspective, the analysis provides a deeper understanding of the way in which social ventures can present themselves to maximize the success of the projects they publish in reward-based crowdfunding platforms. In addition, the study proposes a comprehensive framework that demonstrates how entrepreneurial narratives can be effectively designed on these types of crowdfunding platforms. From a practical perspective, the study also has useful managerial implications for social entrepreneurs whose goal is to effectively present their projects on reward-based crowdfunding platforms.

The remainder of this paper is organized as follows. After a literature review on the strategic role of entrepreneurial narratives in gaining financial resources, a description of the methodological approach is presented. The findings are then described and discussed. In the final section, theoretical and managerial implications are suggested, and the conclusion is presented, including discussion of the limitations of the study and suggestions for further research.

\section{Theoretical background}

Entrepreneurs use project webpages to provide information to people who provide financial resources. Online information plays an important role in the success of entrepreneurial ventures because it can influence investors' decisions, and therefore, the success rate of crowdfunding rounds. Specifically, online information is usually conveyed on the platform website using images, videos, and textual description. Although images and videos also directly improve fundraising performance (Yang et al., 2020), textual description in entrepreneurial narratives plays an important role in the reward crowdfunding model because it contributes to ensuring that potential investors understand the value of the project (Cappa et al., 2020). In addition, entrepreneurial narratives are more crucial for the acquisition of financial resources through reward campaigns than through other crowdfunding models because of particular aspects related to potential backers of reward campaigns (Cappa et al., 2020). That is, backers pledging on reward-based crowdfunding platforms tend to be less interested in and capable of sophisticated investment evaluations based on a venture's economic and financial ratios, and these backers are driven by a complex set of intrinsic and extrinsic motivations (Cholakova \& Clarysse, 2015; Kim \& Viswanathan, 2018).

Entrepreneurial narratives include different elements, for example, stories, myths, metaphors, data, and facts. With specific reference to stories, multiple aspects have been examined in literature. For example, Martens et al. (2007) suggested that stories in entrepreneurial narratives can operate as resource levers in three ways: 1) by conveying an entrepreneurial firm's identity; 2) by elaborating on the logic behind the proposed means of exploiting opportunities; and 3) by incorporating both familiar and unfamiliar contextual elements within narratives. In fact, stories help potential resource providers understand 
in a more simple, coherent, and meaningful way the firm's identity-from its tangible and intangible resources to its mission and morality-and create an emotional bond with stakeholders to foster their trust and support (Miglietta et al., 2015). Stories also help potential backers understand the nature and prospective value of the means proposed by a firm to exploit new growth opportunities by explaining the reasoning behind the strategic initiatives envisaged and giving information about the firm's future potential (Martens et al., 2007). In addition, stories tend to signal the qualities of companies (Ahlers et al., 2015) and emphasize, at various levels, the priorities of entrepreneurs (e.g., orientation to the profit, and risk tolerance) and their values (e.g., diversity, altruism, and benevolence).

Although entrepreneurial narratives in crowdfunding campaigns have been examined in the literature for several years, very few scholars have analyzed the key factors that support a crowdfunding campaign, particularly in relation to reward-based crowdfunding platforms. Manning and Bejarano (2017) highlighted the nine following key factors of entrepreneurial narratives: 1) product information; 2) business model; 3) objectives; 4) motivations; 5) principles; 6) vision; 7) results achieved; 8) resources still required; and 9) how funds will be used. In general, the studies that identify key factors of entrepreneurial narratives pay specific attention to the two following factors: 1) the project description (particularly the length of the text); and 2) the project content in relation to the richness of the information provided about the project and product and the team's skills and the traits of the project's creator. In relation to the first factor, Bi et al. (2017) claimed that more detailed descriptions (i.e., descriptions with more words) are perceived by investors as a signal of project quality and can thus make more investors support the project. In relation to the reward crowdfunding model, narrative description-judged by word count-is considered one of the factors in the success of reward-based crowdfunding campaigns. Lagazio and Querci (2018) tested the hypothesis that the power of textual descriptions in persuading reward crowdfunding investors is higher than that of videos, using the word count as the degree of detail of a description. These authors recommended using at least 500 words and confirmed that potential backers tend to prefer detailed text descriptions, which are more persuasive than videos and thus lead to the successful conclusion of reward campaigns. In general, the length of the description is interpreted as a signal of the quality of the project, given that it is both a good approximation of the level of information and insight provided for the project description (Koch \& Cheng, 2016) and a proxy for the time and effort spent on the description by the project's creator and team. However, Barbi and Bigelli (2017) cautioned against making descriptions too wordy. These researchers claimed that an excessively long description section "could also denote a lack of conciseness of the creator, which is detrimental to readers' attention and to the creator's perceived ability to run the project" (Barbi \& Bigelli, 2017: 211). Honisch et al. (2019) confirmed the importance of short texts in their analysis, which focused on reward projects in the German restaurant industry. 
In relation to the second factor, the description content assumes critical relevance for understanding the potential of entrepreneurial narratives in influencing investors' perceptions and their associated investment decisions. The narrative section of a crowdfunding platform webpage usually describes the project's creator or founder, the project itself, and the way in which the collected funds are going to be used (Levenshus et al., 2019). In addition, to attract the interest of potential backers, entrepreneurial narratives should include an explanation of how the product is manufactured, the phases that have already been realized, and the phases that need to be realized in the future (Lagazio \& Querci, 2018). Along with a detailed description of the project and product, the team's skills and the traits of the project's creator should be described because this increases the interest of potential backers and influences the investment decision (Hoegen et al., 2018). Because of the inability to offer detailed information about every single aspect of a project, entrepreneurs usually emphasize their business idea or their personality and past experience (Butticè et al., 2017; Courtney et al., 2017; Gafni et al., 2019). The extent to which entrepreneurs describe themselves-versus their idea-in the pitch's narrative section is a critical element to be considered. Indeed, the identity of the entrepreneur-that is also the narrator of the narratives - can influence the resolution of the narration paradox, which is the disentanglement of authentic descriptions from misleading ones (Cappa et al., 2020). Davis et al. (2017) claimed that reward crowdfunding performance is positively related to product creativity and highlighted how this relationship is influenced by perceived entrepreneurial passion. Thus, the performance of a crowdfunding round seems to be higher for "funding pitches presented by entrepreneurs who are perceived as highly passionate" (Davis et al., 2017: 101). Anglin et al. (2018a) demonstrated that describing an entrepreneur as "confident, resilient, motivated, and otherwise positively oriented toward taking the needed steps to achieve their goals" (Anglin et al., 2018a: 471) positively influences crowdfunding outcomes. Gafni et al. (2019) claimed that in a reward-based context, particularly for arts-related projects, mentioning the project entrepreneur's name increases success.

However, as stated, very few studies have so far examined the effects of entrepreneurial narratives on investors' decisions. Madrazo-Lemarroy et al. (2019) revealed that the trustworthiness of a project is associated with the cognitive dimensions measured above by text length and the types of words used (e.g., adjectives or qualifiers and sentences or sequences of words). Yeh et al. (2019) argued the importance of explaining a project, its related conception and message(s), future realization plan, and concrete procedure to make investors believe in the feasibility and credibility of the project (Courtney et al., 2017).

The research conducted so far highlights the importance of paying attention to the descriptive text of entrepreneurial narratives because the effects of these narratives influence investors' decisions. However, to the best of our knowledge, identification and discussion of key factors that can contribute to the effective realization of entrepreneurial narratives are scattered throughout the literature and the effects connected to these narratives are rarely examined. Thus, with the purpose of providing an explanatory model, this study examines how to design effective entrepreneurial narratives in reward crowdfunding campaigns for social ventures. 


\section{Methodology}

\section{Research design}

In accordance with the explorative nature of this research, which aims to investigate how social ventures effectively design and communicate their projects for potential investors on crowdfunding platforms, this study adopts an inductive qualitative approach for primary data collection and analysis (Creswell \& Creswell, 2018; Leitch et al., 2010). More precisely, for the research method, this study employs the reward-based crowdfunding platform Eppela as a single in-depth case study and employs entrepreneurial narratives about crowdfunding projects included in Eppela as multiple units of analysis (Yin, 2017). This inductive qualitative methodological approach is appropriate for this research because it enables exploration of social phenomena in their natural state to understand the collected data. Specifically, the case study method "focuses on understanding the dynamics present within single settings" (Eisenhardt, 1989: 534) and is suitable "when a fresh perspective is needed" (Eisenhardt, 1989: 549). Thus, the case study method adopted in this study is not used to confirm or disconfirm previous theories or models but rather to make a solid contribution to the literature about entrepreneurial narratives in crowdfunding campaigns and to draw more general conclusions. In addition, given that the study is based on in-depth analysis of a specific phenomenon that explores dynamics and emerging practices, the results from performing a single case study can be used to further develop research.

Specifically, this research aims to identify key factors (and subfactors) for designing effective entrepreneurial narratives in reward-based campaigns for social ventures. To achieve this, thematic analysis of the crowdfunding projects was performed. However, to identify the expected effects of these entrepreneurial narratives on potential investors, lexical analysis was employed. Both these research techniques are suitable for the exploratory approach adopted by this study because they enable researchers to derive coding categories directly from text. Precisely, thematic analysis enables detection, examination, and description of themes gathered from qualitative data (Braun \& Clarke, 2006) while lexical analysis enables processing of a large amount of text data by condensing, classifying, and structuring that data. This makes data more understandable (Lebart \& Salem, 1994) because it ensures objectivity given that lexical analysis was conducted without interpretation or coding by a mediator through a purely algorithmic method in which data were processed without any preconceptions about the categories to be discovered.

\section{Sampling and data selection procedure}

This study adopted a purposive sampling approach on the Eppela crowdfunding platform. There were four reasons for choosing this crowdfunding platform: 1) it is one of the more active and longest running reward-based crowdfunding platform in the Italian crowdfunding market; 2) it hosts individuals, nonprofit organizations, and for-profit organizations that wish to implement their ideas through bottom-up 
financing; 3) it promotes projects that provide rewards to supporters who can contribute as much as they wish; and 4) it might engage some third parties, such as foundations, referred to as "mentors" in fundraising campaigns, with the aim of fostering innovation and promoting initiatives for collective wellbeing. Our sampling involved the conscious selection of crowdfunding projects in the Eppela platform in relation to the six following criteria considered appropriate for the study aims: 1) the social dimension of the project searching for funds, that is, the project was pursuing a "social aim of serving the community or a specific group of people" (European Commission, 2020: 30) to create collective benefits; 2) the type of firm proposing the project (i.e., for-profit firms proposing a social project); 3) the sector (i.e., technology projects); 4) the model of the fundraising campaign (i.e., all or nothing); 5) the type of round (i.e., successful); and 6) the relevance of the information available in relation to the research objectives. Crowdfunding must be viewed as an alternative way to support initiatives for social purposes to "make societies more sustainable and cohesive through inclusive practices, coproduction, and pro-active grassroots initiatives" (Presenza et al., 2019: 192).

Initially, 28 social projects were identified in the Eppela platform. Of these, only 16 social ventures were identified as eligible for inclusion according to the above criteria.

\section{Data analysis}

To examine the data, two different but complementary analyses were conducted: after undertaking thematic analysis to detect the key factors (and subfactors) of entrepreneurial narratives, lexical analysis was performed to identify the expected effects of these entrepreneurial narratives on potential investors. In the application of both techniques, the corpus of analysis included all the webpages illustrating the crowdfunding pitches of the 16 social ventures selected for the study.

Thematic analysis using NVivo software was applied to identify, examine, and describe key factors and subfactors gathered from the qualitative data. This technique prevents the loss of information through the three following steps: 1) to examine the data corpus (i.e., entrepreneurial narratives about crowdfunding projects in the technology industry that were included in Eppela from 2017 to the end of June $2021)$; 2) to aggregate the data corpus into subfactors; and 3) to identify the key factors. Coding was undertaken conservatively, being based only on what the data explicated. Comparing the codes, similarities and differences were identified, and the number of codes was reduced. In particular, two researchers conducted the coding work separately, and subsequently, they compared their and discussed their coding results and reached agreement on common key factors and subfactors. A blended approach was followed to enable themes to inductively emerge from the data (Miles et al., 2014).

Lexical data analysis using the Alceste method (Lebart \& Salem, 1994; Reinert, 1990) was conducted. After organizing the corpus of analysis into a single file, it was revised to remove typographical and punctuation errors. The coding process for the webpages proceeded as follows: 1) inclusion of full words of meaning as nouns 
subjected to lemmatization, that is, to the transformation from inflected form to the corresponding lemma; 2) elimination of empty words, such as articles, conjunctions, prepositions, and adverbs; 3) exclusion of theme words, that is, words that occur more often in the corpus of entrepreneurial narratives (i.e., are used more frequently) are omitted for the purposes of the analysis; and 4) consideration of words with an occurrence greater than three to enable graphic visibility. All webpages of the 16 social rounds detected were examined via text mining implementing sequentially descending hierarchical classification (DHC) (or hierarchical cluster analysis) and correspondence factor analysis (CFA) (or factor analysis by correspondence) via interface $\mathrm{R}$ for multidimensional text and questionnaire analysis (IRaMuTeQ) (Ratineau \& Marchand, 2012), which is software that employs functionalities provided by the R statistical software. Precisely, DHC allowed the identification of thematic groups (i.e., homogeneous classes of concepts within the textual corpus) by showing the hierarchical relationship between words, while CFA enabled the detection of the relationships between these lexical classes of words in a Cartesian plane.

\section{Factors for effective entrepreneurial narratives in reward-based campaigns for social ventures}

The first goal of this study was to detect key factors and subfactors that enable effective entrepreneurial narrative design in reward crowdfunding campaigns for social ventures. Based on the thematic analysis of the entrepreneurial narratives examined, the five following key factors were identified: 1) problem/need; 2) project; 3) product; 4) team; and 5) venture. Each of these factors include specific subfactors that are presented below along with some exemplary quotations that are proposed as empirical evidence to support the research findings.

\section{Problem/need}

All the 16 social ventures examined for this study have expressly specified the problem that the project aims to resolve or the need that the project aims to meet. Given the social nature of the ventures analyzed, social or sustainable problems/needs are presented in entrepreneurial narratives depending on what the project aims to achieve in relation to society or society and the environment. More precisely, ten entrepreneurial narratives proposed social projects that are fundamentally connected to the fields of healthcare; socialization (e.g., through game) between people (in particular between children with and without a disability); education for diverse groups; physical and digital protection of personal goods (e.g., bicycles or online scams such as advances of money); reduction of dependence on certain products (e.g., smartphones); reuse of unused vouchers and tickets related to leisure time; tax simplification; and the improvement of quality of life of people with disabilities. The following two entrepreneurial narratives describe some of these aspects:

Our project offers smart healthcare to anyone, anytime, anywhere. For schools, the project provides for the distribution of smartcards to students, 
allowing them to always have medical and emergency data available during school hours and during after-school and external activities (sports, afterschool activities and trips). Parents will have the opportunity for "open" communication with the school, which can send push notifications and links to inform them about programs, activities, and emergencies.

The app was born from the desire to solve an increasingly common problem: smartphone addiction and everything that comes with it. And it does so through a game based on a "give-up-reward" mechanism that rewards players for their time spent offline. An innovative system that aims to create awareness of the use of your smartphone, whose unit of measurement is marked by time.

The other six entrepreneurial narratives examined describe sustainable projects because these projects aimed to propose solutions to benefit both society and the environment. Precisely, these projects are connected to sustainable mobility; reuse of products (usually made of plastic); vibration detection of buildings and other structures to discover out-of-standard values; accessibility to recharge systems for individual technological devices; and accessibility of agricultural products in locations that are far from areas of agricultural cultivation. With reference to this last problem, the following entrepreneurial narrative describes its project related to accessibility of agricultural products in locations that are far from areas of agricultural cultivation:

We aim to collect and deliver fruit and vegetables from their lands of origin (Puglia, Basilicata, Campania, and Sicily [Southern Italy]) directly to the final consumer in 24-48 hours (Milan [Northern Italy]). Our unique selling proposition is aimed at zero residue products [...], production with low environmental impact [...], reduction of polluting emissions [...], and orders via e-commerce and app [...].

\section{Project}

All the entrepreneurial narratives analyzed reveal the importance of paying attention to the two following aspects about a project: 1) providing an accurate narrative description of the project proposal; and 2) specifying the goals that the project aims to achieve. To create the description, the entrepreneur proposing the project is helped by the Eppela platform by providing a structure for the narrative through section headings that facilitate describing the project (e.g., "What's this" or "What is it about"); the operation ("How does it work"); and advantages. However, the structure is not fixed and enables project team to add further sections of text. The same headings are freely editable by the proponents of the project. In specifying the goals that the project aims to achieve, the entrepreneurial narratives examined highlight the importance of explicating the purpose of the request for funds. That is, it is fundamental to present for what and how the funds will be used. The following two entrepreneurial narratives explain the purpose of their projects: 
This project aims to create a robot laboratory open to all children (those with and without disability), where socialization, fun, inclusion, and learning are promoted through play.

We want to give each glass the right value, its own history and greater usefulness, ensuring that it is never thrown away. We want to replace the disposable plastic cup with a disposable cup and pass it on to another person: a design object, but also an internet of things device capable of interacting with the real and virtual environment that surrounds it. We combine quality manufacturing with digital services in a glass designed to be used in returnable vacuum.

\section{Product}

Product is the third key factor that emerged from the analysis of the entrepreneurial narratives. Goods and services are described as products in this study. The products proposed in the entrepreneurial narratives include apps (five projects), particularly for use on smartphones, and digital platforms (four projects). Sometimes, the solution is not identified merely as an app, but as a system or a device. This is consistent with the study's decision to examine only social projects proposed by technological ventures. The remainder of the projects proposed a robot, Chabot, smartcard, bike sharing service in cities innovative wheelchair, seismic monitor, and silicone public cup. Precision and attention to detail were employed in each entrepreneurial narrative presenting the product. For example, the innovative wheelchair is described as follows:

An innovative wheelchair that is unique in the world and patented, and which, thanks to a translation system, allows vertical and horizontal movements to the right and left, thus allowing people with disabilities to get as close as possible to autonomy and to enjoy the comfort of the unique seat design, which means there will be no more jolts.

Although the products are technological, entrepreneurial narratives do not offer technical details that are incomprehensible to common understanding. For those who want to deepen their understanding of certain technical characteristics of the product, the entrepreneurial narratives include links to further information on images, audio, or video files, which provide understanding and comparison with similar products. For example:

Bicycle costs four times less than most common GPS [global positioning system] anti-theft devices. The device does not need maintenance, nor to be recharged for three years, after which the battery needs to be replaced. In addition, the Bicycle app offers you the ability to insert photos and descriptions of your bicycle, creating a real "identity card" of the vehicle, which will make it easier to recover in case of theft. In the event of theft, you can track your bicycle's movements on the app. [...] For further information and updates, visit the website www. [...] .com. 


\section{Team}

The team is another key factor of effective entrepreneurial narratives in reward campaigns for social ventures. The entrepreneurial narratives analyzed generally presented the three following aspects of the team members: 1) educational background; 2) skills; and 3) (corporate) role assumed in the social venture. In particular, the narratives described the educational background of the team members, highlighting the relevance of their education to the proposed project. The narratives also described the skills of the team members, particularly the practical competencies each team member had acquired through previous training courses, social ventures, and other professional experience. In describing the (corporate) role, the narratives listed the duties and responsibilities of the social venture and the past role the team had played in similar projects. Interestingly, many of the entrepreneurial narratives presented the interests, passions, and hobbies of the team members as they related to the project. For example:

It was born from an idea of [...], a graduate in management engineering at the Politecnico di Milano, originally from Puglia and heir to a solid family agricultural tradition. Two partners were added to support this idea: a brilliant agri-food engineer from Agrigento, with an agricultural tradition handed down to him from generations, and sole director of [...], with highly valuable expertise in the field of logistics. The project represents the determination and passion of three young guys [...]. Three young people who in turn represent three success stories.

\section{Venture}

Venture is the fifth key factor that emerged from thematic analysis of the entrepreneurial narratives. The narratives for almost all the projects describe the type (e.g., start-up) and history of the venture, as well as the venture's relationships with partner stakeholders. For the type of venture, 15 of the 16 social ventures examined were start-ups. Only one social venture did not specify its nature. Most of the project's presented their history under a section heading that is usually named in the Eppela platform "Who is behind the project" or "A project by". In these descriptions, relationships with partner stakeholders such as manufacturing firms, service organizations, universities, and municipalities are presented by specifying the nature of the collaboration or support. For example:

Our company is registered in the special section of the Business Register dedicated to innovative start-ups. It has already collaborated with Aeroporti di Puglia SpA; Ferrovie Appulo Lucane Srl; Bifest (Bari International Film Festival); Samsung (on the occasion of the Samsung Live 2016 in Milan); G7 Finanze in Bari; G7 in Taormina; G7 Trasporti in Cagliari; and the Giffoni Film Festival. 


\section{Expected effects of entrepreneurial narratives}

The second goal of this study was to identify the expected effects of the entrepreneurial narratives published on the webpages of the Eppela crowdfunding platform by the social ventures. DHC analysis revealed three groups of expected effects that assume critical relevance in the description sections of successful reward campaigns promoted by social ventures to support technological projects. The following three thematic groups of words emerged in relation to their lexical profile as identified by DHC (see the dendrogram in Fig. 1 with the first twenty words for frequency): 1) reassurance; 2) reliability; and 3) credibility. The reassurance expected effect accounted for $29.3 \%$, the reliability expected effect accounted for $31.3 \%$, and the credibility expected effect accounted for $39.4 \%$.

As presented in Fig. 2, the expected effects occupy a well-defined location in the Cartesian plane. Specifically, reassurance is located in the upper area, reliability is located in the lower left area, while credibility is almost completely located in the lower right area of the coordinate space.

\begin{tabular}{|c|c|c|}
\hline credibility & reassurance & reliability \\
\hline $39.4 \%$ & $29.3 \%$ & $31.3 \%$ \\
\hline $\begin{array}{l}\text { firm } \\
\text { innovative } \\
\text { start up } \\
\text { project } \\
\text { marketing } \\
\text { business } \\
\text { university } \\
\text { market } \\
\text { Chabot } \\
\text { idea } \\
\text { platform } \\
\text { responsible } \\
\text { founder } \\
\text { school } \\
\text { degree } \\
\text { engineering } \\
\text { manager } \\
\text { territory } \\
\text { partner } \\
\text { call }\end{array}$ & $\begin{array}{l}\text { app } \\
\text { smartphone } \\
\text { bicycle } \\
\text { community } \\
\text { real } \\
\text { problem } \\
\text { EUR } \\
\text { tool } \\
\text { world } \\
\text { safety } \\
\text { need } \\
\text { cloud } \\
\text { socialization } \\
\text { fee } \\
\text { purchase } \\
\text { device } \\
\text { common } \\
\text { awareness } \\
\text { target } \\
\text { solution }\end{array}$ & $\begin{array}{l}\text { cup } \\
\text { child } \\
\text { user } \\
\text { robot } \\
\text { autism } \\
\text { people } \\
\text { disposable } \\
\text { plastic } \\
\text { ecologic } \\
\text { environment } \\
\text { disabled } \\
\text { humanoid } \\
\text { access } \\
\text { silicone } \\
\text { wheelchair } \\
\text { game app } \\
\text { disability } \\
\text { innovative } \\
\text { event } \\
\text { festival }\end{array}$ \\
\hline
\end{tabular}

Fig. 1 Dendrogram about the expected effects of entrepreneurial narratives in reward crowdfunding campaigns (translated from Italian) 


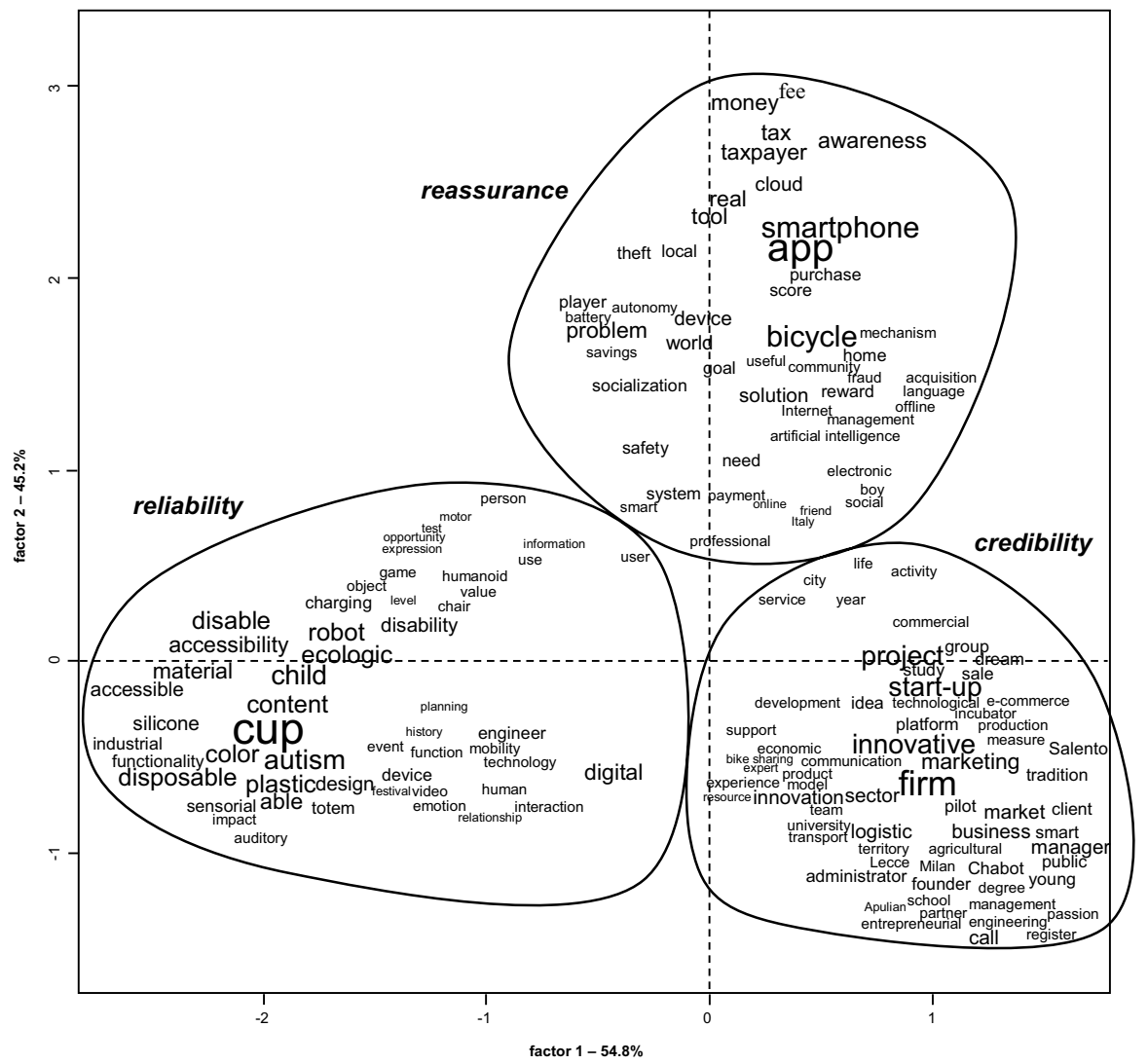

Fig. 2 Expected effects of entrepreneurial narratives in reward campaigns for social ventures on potential investors (translated from Italian)

\section{Reassurance}

Reassurance is one of the expected effects of the entrepreneurial narratives designed by social ventures to ensure maximum contribution to the success of projects in crowdfunding platforms. Specifically, reassuring potential investors is essential to enable them to feel confident about and trust the project, and thus motivate them to evaluate the possibility of financing the project.

The lexical analysis conducted on the entrepreneurial narratives of the 16 projects selected highlighted the importance of having a clear description of the project's purpose. More precisely, the analysis revealed that it is necessary to explain clearly and explicitly the social or sustainability benefits that the project aims to achieve to improve society or the environment rather than the benefits potential investors might enjoy if they invest in the project. In Fig. 2, words such as "community", "world", "socialization", "safety" and "awareness" demonstrate that these entrepreneurial narratives communicate to potential investors the benefits that not only 
they, but the community as a whole might enjoy through the "solutions" proposed by the goods and services offered (which are described with different words such as "app", "smartphone", "bicycle", and "device"). Therefore, entrepreneurial narratives should be designed to provide reassurance to potential investors by describing how the project can resolve "problems" and meet "needs" that are commonly experienced by society, as well as improve the community's quality of life by generating collective utilities and benefits.

\section{Reliability}

Another expected effect of the entrepreneurial narratives is reliability, particularly the reliability of the product offered. Specially, reliability enables potential investors to better understand the project, and thus, to have the information required to evaluate the viability of financing the project.

The entrepreneurial narratives examined inspire belief in the reliability of the product (good or service) by accurately presenting its characteristics. Precisely, the textual analysis reveals that tangible and technological specificities, operational features, ease of use, and accessibility of the product offered are detailed in the entrepreneurial narratives examined. In addition, each of the narratives is connected to the customer segment to which product is addressed. To fulfil this purpose, the narratives create a close relationship between the product and the social benefits it will achieve. Each entrepreneurial narrative carefully explains how "users" or "people" or specific customer segments (e.g., "children" with "auditory", "motor", or visual "disabilities" rather than with "autism") can easily "use" or "access" a certain product (e.g., "humanoid robot", "innovative wheelchair", or "game app") (the words used in Fig. 2 are individually enclosed in quotation marks). Some entrepreneurial narratives explain tests that were conducted before proposing the project to verify the effectiveness of the product (e.g., a laboratory with children). Particular attention is also paid to the usage context of the proposed solution. The entrepreneurial narratives tend to connect this aspect of the project with the sustainability benefits of the product that the community can enjoy. For example, a specific project obtained funding to produce a "cup" that is not "disposable", is rather a use-and-pass "cup" that is made of indestructible "silicone", and thus "ecological" because it is not made of "plastic" and can be used as a returnable vacuum. This product is valuable in multiple contexts of application such as meetings ("events"); cultural occasions ("festivals" and concerts); or entertainment events (dance clubs).

\section{Credibility}

Credibility is the third expected effect to emerge from the analysis of the entrepreneurial narratives. Credibility is here associated with the possibility that the people in the team (and also in the firm) inspire the trust of potential investors, thus enabling them to obtain project financing.

The entrepreneurial narratives analyzed revealed multiple elements that can instill credibility. First, all 16 social ventures considered for this study described 
the nature of their "firm" and many of them (as can be seen from the size of the words in Fig. 2) openly expressed that they are "innovative" "start-ups" by recounting the history of the social venture or how the team was formed. Second, the qualifications, skills, expertise, and corporate roles of each participant in the project were made explicit through words such as "degree" (especially in "engineering") and "founder", "responsible", "manager", and "business partner". In some of the entrepreneurial narratives, the previous personal experience of some team members was presented to communicate their current knowledge of, and skills in relation to, the problem/need that is the subject of project proposed. Third, the narratives explained having established working relationships with other companies or organizations, as well as partnerships with organizations (e.g., a "university" or prestigious company that has previously supported the project) to inspire further credibility. Fourth, some entrepreneurial narratives declared that projects have previously participated in competitive calls by receiving funds that were used to realize the project proposed in the reward-based crowdfunding campaign or a similar previous project. Fifth, one project highlighted that its product had been patented to affirm the importance of this in demonstrating the social venture's credibility in relation to obtaining financing.

\section{Towards an entrepreneurial narrative design model to facilitate the success of social venture crowdfunding campaigns}

The key five factors and the three expected effects of the entrepreneurial narratives can be framed in an entrepreneurial narrative design model to facilitate the success of projects proposed by social ventures in crowdfunding campaigns. Specifically, Fig. 3 (left side) demonstrate how to design an entrepreneurial narrative in structural terms. Precisely, the model highlights the importance of presenting the problem/need of the project by providing an accurate description of the project and its goals; the product in relation to the good or service that is offered; the educational background, skills, interests, passions, and hobbies of the team; and the type and history of the venture that includes past experience of the team with similar social venture projects. Each of these factors can contribute to influencing potential investors.

In addition, Fig. 3 (right side) presents the expected effects of entrepreneurial narratives on potential investors. This means that each entrepreneurial narrative must be designed in such a way that it provides reassurance, reliability, and credibility. That is, the narrative must convince potential investors of the social and/or sustainability benefits of the project, the reliability of the product, the ease of use of the product, and the credibility of the team/venture.

Thus, the model highlights the importance of designing the key factors of entrepreneurial narratives according to the expected effects explained in a way that ensures that potential investors understand, trust, and approve of the project, and thus decide to finance the social venture project. 


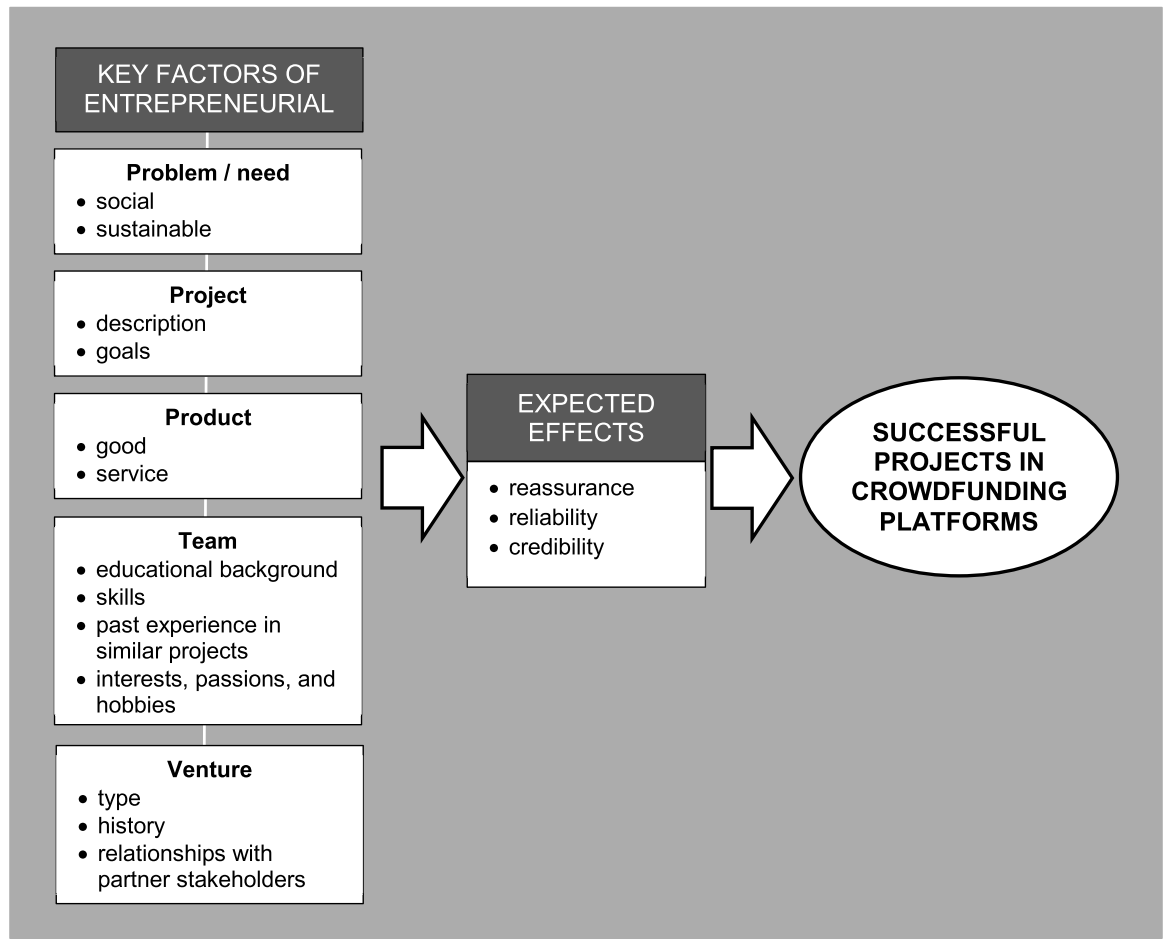

Fig. 3 Model of effective entrepreneurial narrative design to facilitate the success of project funding on reward-based crowdfunding platforms

\section{Discussion}

This study explored the design of effective entrepreneurial narratives in rewardbased crowdfunding platforms by pursuing two goals: 1) detecting key factors (and subfactors) of effective entrepreneurial narrative design in reward crowdfunding campaigns for social ventures; and 2) identifying the expected effects that these entrepreneurial narratives should have on potential investors. In relation to the first goal, the analysis reveals that the key factors for designing effective entrepreneurial narratives are problem/need, project, product, team, and venture. For the first factor (problem/need), the entrepreneurial narrative focuses on the project's final output, which is described as the solution offered to the community through a successful fundraising campaign to solve a specific problem or meet a specific need. Specifically, the analysis of the entrepreneurial narratives demonstrates the importance of making potential investors aware of the benefits they might enjoy through their investment to benefit society or the environment. As the entrepreneurial narratives examined for this study highlight, it is fundamental that potential investors understand the type of solution proposed and recognize the significance of this innovation for the community. This is in line with Allison et al. (2015), who argued that to achieve a successful conclusion for a fundraising 
campaign in the microloan market, it is important to focus on explaining why funding a project would be intrinsically satisfying to the backer.

The results of this research are in line with some previous studies that examine the importance of the factors of project, product, and team in supporting a crowdfunding campaign (e.g., Hoegen et al., 2018; Lagazio \& Querci, 2018; Levenshus et al., 2019; Manning \& Bejarano, 2017). Providing a detailed description of the project and its goals have been identified as a priority in the literature (e.g., Bi et al., 2017; Kunz et al., 2017; Lagazio \& Querci, 2018; Barbi \& Bigelli, 2017; Honisch et al., 2019). In addition, a detailed description of the product plays a fundamental role, particularly in the context analyzed, where the solutions offered are mainly services such as apps, digital platforms, systems, and devices. However, the analysis conducted for this study does not find that describing the entrepreneur's identity and personality is a key factor of entrepreneurial narratives (Butticè et al., 2017; Cappa et al., 2020; Courtney et al., 2017; Davis et al., 2017; Gafni et al., 2019) but does reveal the importance of presenting the entrepreneur and the project team. That is, in line with previous research (Davis et al., 2017), the entrepreneurial narratives examined for this study highlight the role of the passion of the people involved in the project (e.g., the team) in ensuring the success of a crowdfunding campaign. In line with previous literature (e.g., Butticè et al., 2017; Courtney et al., 2017; Gafni et al., 2019), the present research reveals that it is greatly important to present the experience of entrepreneurs and the team in entrepreneurial narratives, and that this is a leading factor in facilitating the success of crowdfunding campaigns.

The fifth key factor that emerged in the analysis is the description of the venture. Most of the social ventures analyzed were start-ups. Crowdfunding is a valuable way for this type of firm to acquire funding (Brown et al., 2018). It is particularly interesting that the entrepreneurial narratives examined included different references to the venture's relationships with various stakeholders (e.g., other firms, universities, centers of research, and municipalities). This aspect outlines the importance of designing effective entrepreneurial narratives by referring to the triple helix model (Etzkowitz \& Leydesdorff, 2000) to highlight the network established with multiple stakeholders (e.g., industry, university, and government).

For the second research goal, reassurance, reliability, and credibility were revealed as the main expected effects of entrepreneurial narratives on potential investors. Precisely, the analysis of the entrepreneurial narratives highlighted that reassurance, reliability, and credibility can be provided by means of the five key factors of the entrepreneurial narratives presented in reward-based crowdfunding platforms. The idea of reassurance implies that in the entrepreneurial narratives, it is important to clarify the social or sustainability benefits that the project will achieve. This is extremely pertinent in the context of reward-based crowdfunding, where backers pledge money mainly for intrinsic motivations such as the desire to participate in a project they believe in or the desire to be actively involved in a community (Cholakova \& Clarysse, 2015) and for social venture fundraising campaigns where backers are likely to be driven by a sense of engagement in such projects (Allison et al., 2015).

The second expected effect is reliability. Research has demonstrated that messages focusing on product quality and usefulness are able to enhance the probability 
of success in crowdfunding campaigns (Allison et al., 2017; Bi et al., 2017). The entrepreneur must describe the project and the product in as much detail as possible to instill confidence in potential backers (Kunz et al., 2017). Incorporating objective information in the description section contributes to reducing uncertainty about the campaign's organization and the deliverables of the promised reward, thus increasing the campaign's success (Tafesse, 2021). Moreover, using formal words in the entrepreneurial narratives can be interpreted as a sign of the professionalism of creators, thus increasing the possibility of the success of the crowdfunding campaign given that potential backers are more likely to have a positive perception of the project if they believe in the professionalism of the creators (Liang et al., 2020).

The third expected effect is credibility. In the context of crowdfunding, research has found that the credibility of the project is connected to the entrepreneur's image and to their past crowdfunding experience, which when presented correctly provide positive signals to investors and foster the legitimacy of the project and the probability of the success of the crowdfunding campaign (Borrero-Domínguez et al., 2020; Courtney et al., 2017). Huang et al. (2021) also found that demonstrating failure experience is important for the success of a crowdfunding campaign because it can be considered a track record of learning and can provide a more realistic picture of the entrepreneurs, thus inspiring greater confidence of potential backers in the project.

While this research is timely, looking beyond the specific analysis context, the study also aims to identify factors that can be used as a source of competitive advantage and a reference guide for entrepreneurs in similar contexts of entrepreneurial narrative design. Thus, Fig. 3 presents a model of how entrepreneurial narratives can effectively contribute to the success of projects in crowdfunding campaigns, including identifying the five key factors of successful entrepreneurial narratives and the effects they have on potential investors.

\section{Implications}

\section{Theoretical implications}

Our study on the textual content of entrepreneurial narratives in reward crowdfunding campaigns for social ventures offers a number of important insights into the fields of entrepreneurship and crowdfunding research. First, this work extends conceptual understanding of narrative theory and research by confirming that an effective entrepreneurial narrative supports the resource attraction process, particularly the acquisition of financial resources, in reward-based crowdfunding campaigns (Allison et al., 2015; Kim et al., 2016; Moss et al., 2015; O’Connor, 2004; Porac et al., 2002).

Second, the analysis provides a deeper understanding of the way in which social ventures can present themselves on reward-based crowdfunding platforms to facilitate the design of an effective entrepreneurial narrative, as well as proposing a comprehensive framework that demonstrates how to design effective entrepreneurial narratives that can maximize the chance of the success of social ventures engaged in 
reward-based crowdfunding. Specifically, the analysis highlights the words on which the examined narratives have based their lexical structure by highlighting the key factors and subfactors of a successful entrepreneurial narrative for social ventures, and the expected effects that these entrepreneurial narratives should have on potential investors. This study thus advances knowledge in the field of entrepreneurial narratives by investigating the fundamental elements of such narratives.

Third, it is our understanding that entrepreneurship and crowdfunding research has paid little attention to how social ventures can effectively empower crowdfunding campaigns in relation to textual content. From this perspective, text mining analysis of entrepreneurial narratives involving the single words used should be incorporated more systematically into future theorizing and empirical research in this area. This would deepen knowledge of successful crowdfunding campaign outcomes in relation to the textual content of entrepreneurial narratives through a bag-of-words text mining approach. Very few scholars (e.g., Siering et al., 2016) have adopted this approach to examining the strategic factors associated with entrepreneurial narratives on reward-based crowdfunding platforms. Moreover, we propose that it is important to consider whether a text narrative can be influenced by the context in which the entrepreneur operates. This would help to explain how the textual boundaries of a narrative approach to entrepreneurship research-with reference to rewardbased crowdfunding campaigns_-are delineated.

\section{Managerial implications}

The results of this study suggest that social entrepreneurs should not (naively) commit the mistake of thinking that it is sufficient to write only several lines on webpages dedicated to projects on crowdfunding platforms to attract the attention of users. With the increasing success of the crowdfunding model, thousands of projects are competing in this context. Accordingly, competition is becoming progressively heated, and entrepreneurs must therefore adopt a structured process in which effective narrative plays a strategic role. When writing the narrative section, entrepreneurs should be engaging and provide the most important information about the problem or need addressed by the project, the project itself, and the product that will be realized, while also specifying the team's and venture's profiles in relation to the team members, their past experience, and networking. The development of networking is particularly important because it allows the creation of reciprocal connections (and therefore exchange) between multiple systems, thus favoring the development of valuable relationships. Networking allows the company to acquire new knowledge and share its experience through highlighting its distinctive skills; it also allows the company to activate new collaborations and stimulate an exchange within a qualified community such as that represented by the system of relationships created to support its own project and other potential investment projects. The company's project thus becomes a resource recognized by a network that provides benefit by improving collective wellbeing.

The results of this study suggest that social entrepreneurs who are presenting their project must not focus only on the request for funding, but also on telling both an appealing and a sustainable (in social and environmental terms) narrative that makes backers want to participate in the project. 
This study invites entrepreneurs to ask themselves the following questions: What information should be conveyed? How can the entrepreneurial narrative be effectively established? These answers to these questions must lead entrepreneurs to reflect on the descriptions and aims of the project and on the product specificities through which they can establish a relationship with users and engage them. Therefore, the importance of specifying to whom the project is addressed and of presenting in detail the creative idea and innovative product to the intended audience is highlighted by this study.

In relation to the project goals, this study highlights the importance of explaining in detail the purpose of the request for funds by communicating for what and how the funds will be used. Referring to the specific, measurable, assignable, realistic, and timely (SMART) method proposed in management literature (Doran, 1981) —a method that is commonly considered the standard for writing effective goals (e.g., Bjerke \& Renger, 2017)—entrepreneurs should formulate a project's goals to ensure they are specific, measurable, assignable, realistic, and timely. Therefore, it is advisable that an entrepreneurial narrative clearly defines what the project intends to achieve and establishes measurable criteria to track the progress of the project and remain motivated. Goals must also be accurate and attainable to be successful, as well as aligned with other relevant aims and subjected to a deadline that provides a goal on which to focus and a point in time to work toward.

Although the use of videos, pictures, blogs, and other online elements is increasing because of their visual power to capture users' attention (e.g., Kaminski \& Hopp, 2020; Kraus et al., 2016; Mollick, 2014; Petitjean, 2018; Zheng et al., 2014), similar to previous studies (Barbi \& Bigelli, 2017; Honisch et al., 2019; Kaminski \& Hopp, 2020; Lagazio \& Querci, 2018), this research reveals that entrepreneurial narratives can persuade reward crowdfunding investors.

Thus, this study suggests that entrepreneurs should carefully develop their business writing skills. In particular, they should attend appropriate training courses or rely on external consultancy services or professional copyeditors to write interesting text if they have not already developed these specific skills.

This research also suggests that entrepreneurs must create a narrative that is able to provide reassurance, reliability, and credibility through highlighting the firm's ability to share its experience and attract collaborations and partnerships with public and private research institutions and other institutions of local, national, and international relevance to boost innovation and technology transfer. Entrepreneurial narratives should also focus on describing and highlighting the results of their research, their introduction of innovative products on the market, and their registering of patents to strengthen the firm's image of being competitive in relation to innovation, design, corporate identity, and planning.

\section{Conclusions}

By performing thematic and lexical analysis, this study detected the key factors and the expected effects of entrepreneurial narratives in successful reward crowdfunding rounds promoted by social ventures to support their technological projects. The key factors and the expected effects were framed into a model to 
demonstrate how to design an effective entrepreneurial narrative. The following five strategic factors were found by the study: a clear definition of the problem or need to be solved, a specific description of the project and the aims the firm intends to realize, a presentation of the product (goods and services) that will be offered to the target, a presentation of the skills, practical competencies, and roles of team members involved in the project, and the sharing of information about the venture history and of the main partnerships developed to support the project. For the expected effects of effective entrepreneurial narratives, this study identified the critical relevance of providing reassurance, reliability, and credibility in potential investors. These effects support better understanding of the project, develop the target audience's trust in the project, and reinforce the possibility that the project can be approved and funded.

This study has several limitations that should be overcome in future research. First, the quality of the narrative (specifically, how the idea/project is presented and "sold" to potential investors matters) is a factor that influences the level of success of crowdfunding campaigns, but this is not the single indicator of that success (or failure). The isolation of the effect of the narrative is not the aim of this study, and it cannot be assumed that having an excellent narrative will ensure a crowdfunding campaign will succeed. Second, there is a limitation in generalizing our findings to different types of crowdfunding campaigns. Our investigation focused on entrepreneurial narratives connected to projects developed by social ventures operating in the technology sector. Future research could examine how entrepreneurs operating in other sectors describe their social ventures and nontechnology projects from the textual content perspective. Third, the study findings may be affected by the specificities of the Italian platform case study Eppela. Future research could investigate entrepreneurial narratives on different crowdfunding and media platforms. From this perspective, the narratives on different platforms could also be compared by means of a cross-country analysis. Fourth, the study does not employ longitudinal data. The analysis was able to capture a potentially critical moment of narrative construction in entrepreneurial processes through crowdfunding campaigns. Future research should seek to investigate how narratives can change over time.

There are many intriguing directions for future research adopting a narrative approach to entrepreneurial phenomena. One suggestion is to collect data on the perception of campaigns by audiences and the way they respond to entrepreneurial narratives on reward-based crowdfunding platforms. To achieve this, various descriptions of narratives could be tested with different audiences and analyzed for different types of projects to better contextualize their effectiveness. Moreover, further research might analyze the association between text narratives and backers' motivations. In addition, as creators can have diverse motivations for launching campaigns beyond raising funds (e.g., expanding awareness, establishing networks and testing markets) (Ryu et al., 2020), campaigns may vary in their narrative descriptions and have different effects on funding strategies. Future research could also extend the literature exploring the strategic importance of narrative text on a communicative level (e.g., Frydrych et al., 2014). Several studies have focused on how entrepreneurs communicate their ideas or projects 
to potential backers on crowdfunding platforms through videos, pictures, blogs, and other online elements (e.g., Mollick, 2014; Xiao et al., 2014; Cordova et al., 2015; Kraus et al., 2016; Petitjean, 2018; Koch \& Siering, 2019; Kaminski \& Hopp, 2020). However, few studies have examined factors such as how message strategy can effectively empower entrepreneurial narrative design for social ventures engaged in reward crowdfunding round. Short and Anglin (2019: 11) claimed that "messages may likely need to be tailored toward the specific crowdfunding platform chosen for funding". Thus, future research should examine the relevance of the content of the social venture campaign and the effect of this content on campaign performance given that previous research (Anglin et al., 2014, 2018b; Belleflamme et al., 2014; Kaminski \& Hopp, 2020; Kraus et al., 2016) has focused on communication style, rhetoric, and sentiment analysis. Another interesting focus could be the analysis of reward-based crowdfunding platforms narratives for projects promoted by B Corporations, a recent type of business that balances purpose and profit (e.g., Mion \& Loza Adaui, 2020; Riolfo, 2020). These firms are legally required to consider the effect of their decisions on their workers, customers, suppliers, community, and the environment, and are thus leading a global movement of people who use business as a force for good. Furthermore, it could be of interest analyzing the reward-based crowdfunding platforms narratives for projects promoted by NGOs or non-profit organizations, or even regular companies, following a particular pattern, in order to understand if they behave differently than a social venture. A further stimulus for reflection concerns the pandemic effect. One aspect to examine could be whether the pandemic could have had any influence on the investigated narratives and the type of projects to be funded. The focus of this research has been technological social ventures, and digital technologies have received a strong boost due to the pandemic, despite the general reduction in activity. In addition, a stimulating analysis might be examining the association between narrative text and different narration styles. Future research should also further link the case analyzed here to other contexts of entrepreneurial narrative construction, such as marketing and media campaigns and project presentations. Finally, this study stimulates further research aiming to identify the performance implications of adopting certain types of narrative text in entrepreneurial processes-both in and beyond the context of crowdfunding.

\section{References}

Acs, Z. J., Boardman, M. C., \& McNeely, C. L. (2013). The social value of productive entrepreneurship. Small Business Economics, 40(3), 785-796. https://doi.org/10.1007/s11187-011-9396-6

Ahlers, G. K. C., Cumming, D., Günther, C., \& Schweizer, D. (2015). Signaling in equity crowdfunding. Entrepreneurship Theory and Practice, 39(4), 955-980. https://doi.org/10.1111/etap.12157

Allison, T. H., Davis, B. C., Short, J. C., \& Webb, J. W. (2015). Crowdfunding in a prosocial microlending environment: Examining the role of intrinsic versus extrinsic cues. Entrepreneurship Theory and Practice, 39(1), 53-73. https://doi.org/10.1111/etap.12108

Allison, T. H., Davis, B. C., Webb, J. W., \& Short, J. C. (2017). Persuasion in crowdfunding: An elaboration likelihood model of crowdfunding performance. Journal of Business Venturing, 32(6), 707725. https://doi.org/10.1016/j.jbusvent.2017.09.002 
Anglin, A. H., Allison, T. H., McKenny, A. F., \& Busenitz, L. W. (2014). The role of charismatic rhetoric in crowdfunding: An examination with computer-aided text analysis. Social Entrepreneurship and Research Methods, 9, 19-48. https://doi.org/10.1108/S1479-838720140000009010

Anglin, A. H., Short, J. C., Drover, W., Stevenson, R. M., McKenny, A. F., \& Allison, T. H. (2018a). The power of positivity? The influence of positive psychological capital language on crowdfunding performance. Journal of Business Venturing, 33(6), 470-492. https://doi.org/10.1016/j.jbusvent.2018. 03.003

Anglin, A. H., Wolfe, M. T., Short, J. C., McKenny, A. F., \& Pidduck, R. J. (2018b). Narcissistic rhetoric and crowdfunding performance: A social role theory perspective. Journal of Business Venturing, 33(6), 780-812. https://doi.org/10.1016/j.jbusvent.2018.04.004

Austin, J., Stevenson, H., \& Wei-Skillern, J. (2006). Social and commercial entrepreneurship: Same, different or both?". Entrepreneurship Theory and Practice, 30(1), 1-22. https://doi.org/10.1111/2Fj. 1540-6520.2006.00107.x

Baber, H. (2020). Secret of successful crowdfunding campaigns. Advances in Business-Related Scientific Research Journal, 11(2), 17-31.

Barbi, M., \& Bigelli, M. (2017). Crowdfunding practices in and outside the US. Research in International Business and Finance, 42(December), 208-223. https://doi.org/10.1016/j.ribaf.2017.05.013

Belleflamme, P., Lambert, T., \& Schwienbacher, A. (2014). Crowdfunding: Tapping the right crowd. Journal of Business Venturing, 29(5), 585-609. https://doi.org/10.1016/j.jbusvent.2013.07.003

Bi, S., Liu, Z., \& Usman, K. (2017). The influence of online information on investing decisions of reward-based crowdfunding. Journal of Business Research, 71(February), 10-18. https://doi.org/10. 1016/j.jbusres.2016.10.001

Bjerke, M. B., \& Renger, R. (2017). Being smart about writing SMART objectives. Evaluation and Program Planning, 61(April), 125-127. https://doi.org/10.1016/j.evalprogplan.2016.12.009

Boeuf, B., Darveau, J., \& Legoux, R. (2014). Financing creativity: Crowdfunding as a new approach for theatre projects. International Journal of Arts Management, 16(3), 33-48.

Bonfanti, A., Battisti, E., \& Pasqualino, L. (2016). Social entrepreneurship and corporate architecture: Evidence from Italy. Management Decision, 54(2), 390-417. https://doi.org/10.1108/ MD-08-2014-0532

Borrero-Domínguez, C., Cordón-Lagares, E., \& Hernández-Garrido, R. (2020). Analysis of success factors in crowdfunding projects based on rewards: A way to obtain financing for socially committed projects. Heliyon, 6, 1-9. https://doi.org/10.1016/j.heliyon.2020.e03744

Braun, V., \& Clarke, V. (2006). Using thematic analysis in psychology. Qualitative Research in Psychology, 3(2), 77-101. https://doi.org/10.1191/1478088706qp063oa

Brown, R., Mawson, S., Rowe, A., \& Mason, C. (2018). Working the crowd: Improvisational entrepreneurship and equity crowdfunding in nascent entrepreneurial ventures. International Small Business Journal: Researching Entrepreneurship, 36(2), 169-193. https://doi.org/10.1177/2F0266242617729743

Butticè, V., Colombo, M. G., \& Wright, M. (2017). Serial crowdfunding, social capital, and project success. Entrepreneurship Theory and Practice, 41(2), 183-207. https://doi.org/10.1111/etap.12271

Cambridge Centre for Alternative Finance. (2019). Shifting Paradigms. The $4^{\text {th }}$ European Alternative Finance Benchmarking Report, from https://www.jbs.cam.ac.uk/faculty-research/centres/alternativefinance/publications/shifting-paradigms/

Cambridge Centre for Alternative Finance. (2020). The Global Alternative Finance Market Benchmarking Report, from https://www.jbs.cam.ac.uk/faculty-research/centres/alternative-finance/publications/theglobal-alternative-finance-market-benchmarking-report/

Cappa, F., Pinelli, M., Maiolini, R., \& Leone, M. I. (2020). "Pledge" me your ears! The role of narratives and narrator experience in explaining crowdfunding success. Small Business Economics, 57, 953-973. https://doi.org/10.1007/s11187-020-00334-y

Carini, C., \& Lori, M. (2020). Dimensioni e caratteristiche delle imprese sociali. In C. Borzaga, \& M. Musella (Eds.) L'impresa sociale in Italia. Identità, ruoli e resilienza, IV Rapporto Iris Network, from https://irisnetwork.it/2021/04/impresa-sociale-quarto-rapporto-download/

Chan, C. S., \& Parhankangas, A. (2017). Crowdfunding innovative ideas: How incremental and radical innovativeness influence funding outcomes. Entrepreneurship Theory and Practice, 41(2), 237-263. https://doi.org/10.1111/etap.12268

Chiaf, E. (2020). Il contributo dell'impresa sociale alla creazione di valore e all'occupazione. Aspetti quantitativi e qualitative. In C. Borzaga, \& M. Musella (Eds.) L'impresa sociale in Italia. Identità, ruoli e resilienza, IV Rapporto Iris Network, from https://irisnetwork.it/2021/04/impresa-socialequarto-rapporto-download/ 
Choi, N., \& Majumdar, S. (2014). Social entrepreneurship as an essentially contested concept: Opening a new avenue for systematic future research. Journal of Business Venturing, 29(3), 363-376. https:// doi.org/10.1016/j.jbusvent.2013.05.001

Cholakova, M., \& Clarysse, B. (2015). Does the possibility to make equity investments in crowdfunding projects crowd out reward-based investments? Entrepreneurship Theory and Practice, 39(1), 145-172. https://doi.org/10.1111/etap.12139

Colombo, M. G., Franzoni, C., \& Rossi-Lamastra, C. (2015). Internal social capital and the attraction of early contributions in crowdfunding. Entrepreneurship Theory and Practice, 39(1), 75-100. https:// doi.org/10.1111/etap.12118

Cordova, A., Dolci, J., \& Gianfrate, G. (2015). The determinants of crowdfunding success: Evidence from technology projects. Procedia - Social and Behavioral Sciences, 181(May), 115-124. https:// doi.org/10.1016/j.sbspro.2015.04.872

Courtney, C., Dutta, S., \& Li, Y. (2017). Resolving information asymmetry: Signaling, endorsement, and crowdfunding success. Entrepreneurship Theory and Practice, 41(2), 265-290. https://doi.org/10. 1111/etap.12267

Creswell, J. W., \& Creswell, J. D. (2018). Research design: Qualitative, quantitative, and mixed methods approaches. Sage.

Davis, B. C., Hmieleski, K. M., Webb, J. W., \& Coombs, J. E. (2017). Funders' positive affective reactions to entrepreneurs' crowdfunding pitches: The influence of perceived product creativity and entrepreneurial passion. Journal of Business Venturing, 32(1), 90-106. https://doi.org/10.1016/j. jbusvent.2016.10.006

Doran, G. T. (1981). There's a S.M.A.R.T. way to write management's goals and objectives. Management Review, 70(11), 35-36.

Eisenhardt, K. M. (1989). Building theories from case study research. Academy of Management Review, 14(4), 532-550. https://doi.org/10.2307/258557

Etchart, N., \& Comolli, L. (2013). Social enterprise in emerging market countries. No Free Ride. Palgrave Macmillan.

Etzkowitz, H., \& Leydesdorff, L. (2000). The dynamics of innovation: From national systems and "Mode 2" to a triple helix of university-industry-government relations. Research Policy, 29(2), 109-123. https://doi.org/10.1016/S0048-7333(99)00055-4

European Commission. (2020). Social enterprises and their ecosystems in Europe. Comparative synthesis report, from https://europa.eu/!Qq64ny

Fedele, A., \& Miniaci, R. (2010). Do social enterprises finance their investments differently from forprofit firms? The case of social residential services in Italy. Journal of Social Entrepreneurship, 1(2), 174-189. https://doi.org/10.1080/19420676.2010.511812

Frydrych, D., Bock, A. J., Kinder, T., \& Koeck, B. (2014). Exploring entrepreneurial legitimacy in reward-based crowdfunding. Venture Capital, 16(3), 247-269. https://doi.org/10.1080/13691066. 2014.916512

Gafni, H., Marom, D., \& Sade, O. (2019). Are the life and death of an early-stage venture indeed in the power of the tongue? Lessons from online crowdfunding pitches. Strategic Entrepreneurship Journal, 13(1), 3-23. https://doi.org/10.1002/sej.1293

Guo, F., Zou, B., Guo, J., Shi, Y., Bo, Q., \& Shi, L. (2019). What determines academic entrepreneurship success? A social identity perspective. International Entrepreneurship and Management Journal, 15, 929-952. https://doi.org/10.1007/s11365-019-00569-6

Hoegen, A., Steininger, D. M., \& Veit, D. (2018). How do investors decide? An interdisciplinary review of decision-making in crowdfunding. Electron Markets, 28, 339-365. https://doi.org/10.1007/ s12525-017-0269-y

Honisch, E., Harrington, R. J., \& Ottenbacher, M. C. (2019). Crowdfunding: Preparation considerations and success factors for the German restaurant sector. International Journal of Hospitality \& Tourism Administration, 20(2), 182-205. https://doi.org/10.1080/15256480.2017.1359733

Huang, S., Pickernell, D., Battisti, M., \& Nguyen, T. (2021). Signalling entrepreneurs' credibility and project quality for crowdfunding success: Cases from the Kickstarter and Indiegogo environments Small Business Economics, 1-21. https://doi.org/10.1007/s11187-021-00477-6

Isnet. (2020). XIV Osservatorio Isnet sulle imprese sociali, from http://www.impresasociale.net/osservatorio/ xiv_osservatorio_isnet_-_comunicato_post_evento.php 
Kaminski, J. C., \& Hopp, C. (2020). Predicting outcomes in crowdfunding campaigns with textual, visual, and linguistic signals. Small Business Economics, 55(4), 627-649. https://doi.org/10.1007/ s11187-019-00218-w

Kerlin, J. (2010). A comparative analysis of the global emergence of social enterprise. Voluntas: International Journal of Voluntary and Nonprofit Organizations, 21(2), 162-179. https://doi.org/10.1007/ s11266-010-9126-8

Kim, K., \& Viswanathan, S. (2018). The experts in the crowd: The role of experienced investors in a crowdfunding market. MIS Quarterly, 43(2), 347-372. https://doi.org/10.25300/MISQ/2019/13758

Kim, P. H., Buffart, M., \& Croidieu, G. (2016). TMI: Signaling credible claims in crowdfunding campaign narratives. Group \& Organization Management, 41(6), 717-750. https://doi.org/10.1177/ 1059601116651181

Koch, J. A., \& Siering, M. (2019). The recipe of successful crowdfunding campaigns. Electronic Markets, 29(4), 661-679. https://doi.org/10.1007/s12525-019-00357-8

Koch, J. A., \& Cheng, Q. (2016). The role of qualitative success factors in the analysis of crowdfunding success: Evidence from Kickstarter. Proceedings of the $20^{\text {th }}$ Pacific Asia Conference on Information Systems (PACIS 2016), Chiayi, May 29, from https://ssrn.com/abstract=2808428

Kraus, S., Richter, C., Brem, A., Cheng, C. F., \& Chang, M. L. (2016). Strategies for reward-based crowdfunding campaigns. Journal of Innovation \& Knowledge, 1(1), 13-23. https://doi.org/10. 1016/j.jik.2016.01.010

Kunz, M., Bretschneider, U., Erler, M., \& Leimeister, J. (2017). An empirical investigation of signaling in reward-based crowdfunding. Electronic Commerce Research, 17(3), 425-461. https://doi.org/10. 1007/s10660-016-9249-0

Lagazio, C., \& Querci, F. (2018). Exploring the multi-sided nature of crowdfunding campaign success. Journal of Business Research, 90(C), 318-324. https://doi.org/10.1016/j.jbusres.2018.05.031

Lebart, L., \& Salem, A. (1994). Statistique textuelle. Dunod.

Lehner, O. M. (2013). Crowdfunding social ventures: A model and research agenda. Venture Capital, 15(4), 289-311. https://doi.org/10.1080/13691066.2013.782624

Lehner, O. M., \& Nicholls, A. (2014). Social finance and crowdfunding for social enterprises: A publicprivate case study providing legitimacy and leverage. Venture Capital., 16(3), 271-286. https://doi. org/10.1080/13691066.2014.925305

Leitch, C. M., Hill, F. M., \& Harrison, R. T. (2010). The philosophy and practice of interpretivist research in entrepreneurship: Quality, validation, and trust. Organizational Research Methods, 13(1), 67-84. https://doi.org/10.1177/2F1094428109339839

Levenshus, A. B., Lemon, L. L., Childers, C., \& Cho, M. (2019). "I thought they'd do more": Conflicting expectations of crowdfunding communication. Journal of Communication Management, 23(2), 123-141. https://doi.org/10.1108/JCOM-03-2018-0024

Liang, X., Hu, X., \& Jiang, J. (2020). Research on the effects of information description on crowdfunding success within a sustainable economy - The perspective of information communication. Sustainability, 12(2), 1-36. https://doi.org/10.3390/su12020650

Madrazo-Lemarroy, P., Barajas-Portas, K., \& Labastida Tovar, M. E. (2019). Analyzing campaign's outcome in reward-based crowdfunding. Social capital as a determinant factor. Internet Research, 29(5), 1171-1189. https://doi.org/10.1108/INTR-03-2018-0115

Mair, J., \& Martí, I. (2006). Social entrepreneurship research: A source of explanation, prediction, and delight. Journal of World Business, 41(1), 36-44. https://doi.org/10.1016/j.jwb.2005.09.002

Manning, S., \& Bejarano, T. A. (2017). Convincing the crowd: Entrepreneurial storytelling in crowdfunding campaigns. Strategic Organization, 15(2), 194-219. https://doi.org/10.1177/1476127016648500

Martens, M. L., Jennings, J. E., \& Jennings, P. D. (2007). Do the stories they tell get them the money they need? The role of entrepreneurial narratives in resource acquisition. Academy of Management Journal, 50(5), 1107-1132. https://doi.org/10.2307/20159915

McKenny, A. F., Allison, T. H., Ketchen, D. J. Jr., Short, J. C., \& Ireland, R. D. (2017). How Should Crowdfunding Research Evolve? A Survey of the Entrepreneurship Theory and Practice Editorial Board. Entrepreneurship Theory and Practice, 291-304. https://doi.org/10.1111/etap.12269

Miglietta, A., Romenti, S., \& Sartore, A. (2015). Entrepreneurial narratives for resource acquisition in the Italian creative industries. A qualitative study. Sinergie Italian Journal of Management, 33(98), 213-231. https://doi.org/10.7433/s98.2015.13

Miles, M. B., Huberman, A. M., \& Saldana, J. (2014). Qualitative data analysis: A methods sourcebook. Sage. 
Mion, G., \& Loza Adaui, C. R. (2020). Understanding the purpose of benefit corporations: An empirical study on the Italian case. International Journal of Corporate Social Responsibility, 5(4), 1-15. https://doi.org/10.1186/s40991-020-00050-6

Mollick, E. (2014). The dynamics of crowdfunding: An exploratory study. Journal of Business Venturing, 29(1), 1-16. https://doi.org/10.1016/j.jbusvent.2013.06.005

Moss, T. W., Neubaum, D. O., \& Meyskens, M. (2015). The effect of virtuous and entrepreneurial orientations on microfinance lending and repayment: A signaling theory perspective. Entrepreneurship Theory and Practice, 39(1), 27-52. https://doi.org/10.1111/etap.12110

Nicholls, A. (2008). Social entrepreneurship: New models of sustainable social change. Oxford University Press.

O'Connor, J. (2004). Storytelling to be real: Narrative, legitimacy building and venturing. Narrative and Discursive Approaches in Entrepreneurship: A Second Movements in Entrepreneurship Book. Cheltenham, UK: Edward Elgar Publishing.

Petitjean, M. (2018). What explains the success of reward-based crowdfunding campaigns as they unfold? Evidence from the French crowdfunding platform KissKissBankBank. Finance Research Letters, 26(September), 9-14. https://doi.org/10.1016/j.frl.2017.11.005

Porac, J. F., Mishina, Y., \& Pollock, T. (2002). Entrepreneurial narratives and the dominant logics of high growth firms. In A. Huff \& M. Jenkins (Eds.), Mapping strategic knowledge (pp. 112-136). Sage.

Presenza, A., Abbate, T., Cesaroni, F., \& Appio, F. P. (2019). Enacting social crowdfunding business ecosystems: The case of the platform Meridonare. Technological Forecasting \& Social Change, 143, 190-201. https://doi.org/10.1016/j.techfore.2019.03.001

Ratineau, P., \& Marchand, P. (2012). Application de la méthode ALCESTE à de "gros" corpus". 11eme Journées d'Analyse statistique des Données Textuelles (pp. 835-844).

Reinert, M. (1990). Alceste une méthodologie d'analyse des données textuelles et une application: Aurelia de Gerard de Nerval. Bulletin De Méthodologie Sociologique, 26(1), 24-54. https://doi.org/10. 1177/075910639002600103

Ridley-Duff, R. (2008). Social enterprise as a socially rational business. International Journal of Entrepreneurial Behaviour \& Research, 14(5), 291-312. https://doi.org/10.1108/13552550810897669

Riolfo, G. (2020). The new Italian benefit corporation. European Business Organization Law Review, 21 , 279-317. https://doi.org/10.1007/s40804-019-00149-9

Robertson, E., \& Wooster, R. B. (2015). Crowdfunding as a social movement: The determinants of success in Kickstarter campaigns (July 15), from https://ssrn.com/abstract=2631320 or https://doi.org/ $10.2139 /$ ssrn. 2631320

Ryu, S., Park, J., Kim, K., \& Kim, Y. G. (2020). Reward versus altruistic motivations in reward-based crowdfunding. International Journal of Electronic Commerce, 24(2), 159-183. https://doi.org/10. 1080/10864415.2020.1715531

Short, J. C., \& Anglin, A. H. (2019). Is leadership language 'rewarded' in crowdfunding? Replicating social entrepreneurship research in a rewards-based context. Journal of Business Venturing Insights, 11(June), 1-13. https://doi.org/10.1016/j.jbvi.2019.e00121

Siering, M., Koch, J.-A., \& Deokar, A. V. (2016). Detecting fraudulent behavior on crowdfunding platforms: The role of linguistic and content-based cues in static and dynamic contexts. Journal of Management Information Systems, 33(2), 421-455. https://doi.org/10.1080/07421222.2016.1205930

Tafesse, W. (2021). Communicating crowdfunding campaigns: How message strategy, vivid media use and product type influence campaign success. Journal of Business Research, 127(April), 252-263. https://doi.org/10.1016/j.jbusres.2021.01.043

Xiao, S., Tan, X., Dong, M., \& Qi, J. (2014). How to design your project in the online crowdfunding market? Evidence from Kickstarter. $35^{\text {th }}$ International Conference on Information Systems, 14-17 December. Auckland: Association for Information Systems, from https://www. semanticscholar.org/paper/How-to-Design-Your-Project-in-the-Online-Market-Xiao-Tan/ ddbf6d95218f6f2654a45e06c785bd62732d6a2a

Yang, J., Li, Y., Calic, G., \& Shevchenko, A. (2020). How multimedia shape crowdfunding outcomes: The overshadowing effect of images and videos on text in campaign information. Journal of Business Research, 117(September), 6-18. https://doi.org/10.1016/j.jbusres.2020.05.008

Yeh, T. L., Chen, T. Y., \& Lee, C. C. (2019). Investigating the funding success factors affecting reward-based crowdfunding projects. Innovation, 21(3), 466-486. https://doi.org/10.1080/14479338.2019.1585191

Yin, R. K. (2017). Case Study Research and Applications: Design and Methods. Sage. 
Zheng, H., Li, D., Wu, J., \& Xu, Y. (2014). The role of multidimensional social capital in crowdfunding: A comparative study in China and US. Information \& Management, 51(4), 488-496. https://doi.org/ 10.1016/j.im.2014.03.003

Publisher's Note Springer Nature remains neutral with regard to jurisdictional claims in published maps and institutional affiliations.

\title{
Authors and Affiliations
}

\section{Veronica De Crescenzo ${ }^{1}$ (D) . Angelo Bonfanti ${ }^{1}$ (D) $\cdot$ Paola Castellani $^{1}$ (D) . Alfonso Vargas-Sánchez ${ }^{2}$}

\author{
Angelo Bonfanti \\ angelo.bonfanti@univr.it \\ Paola Castellani \\ paola.castellani@univr.it \\ Alfonso Vargas-Sánchez \\ vargas@uhu.es \\ 1 Department of Business Administration, University of Verona, Verona, Italy \\ 2 Department of Management and Marketing, University of Huelva, Huelva, Spain
}

